\title{
PATTERNS OF FIREWOOD USE AMONG ETHNIC MINORITY COMMUNITIES AND LOCAL FOREST MANAGEMENT: A CASE STUDY IN PU HU NATURE RESERVE, VIETNAM
}

\author{
TeChato, $\mathrm{P}^{1}{ }^{1}-$ TeChato, $\mathrm{K}^{2,3^{*}}$ \\ ${ }^{I}$ Faculty of Sports Science and Health, Institute of Physical Education \\ Trang Campus, Trang, Thailand \\ ${ }^{2}$ Faculty of Environmental Management, Prince of Songkla University \\ Hat Yai, 90110 Songkhla, Thailand \\ ${ }^{3}$ Environmental Assessment and Technogy for Hazardous Waste Management, \\ Faculty of Environmental Management, Prince of Songkla University \\ Hat Yai, 90110 Songkhla, Thailand \\ *Corresponding author \\ e-mail:uhugua@hotmail.com \\ (Received $2^{\text {nd }}$ May 2018; accepted 20 Jun 2018)
}

\begin{abstract}
In Vietnam as in other developing countries, firewood, including biomass is very important in rural areas as the main energy source and a part of the subsistence livelihood for ethnic minority communities. Rangers still carry out patrol activity for reducing the firewood collection inside nature reserve areas. However, before this study, little research had been conducted in the buffer zone of Pu $\mathrm{Hu}$ nature reserve (NR). The study was conducted to obtain an understanding of household firewood used, and the factors which influence firewood consumption. The methodology included questionnaires, observing household practices, and in-depth interviews with village leaders and local rangers with patrol activity currency. A survey of 248 households was conducted in five villages including households from all three ethnic minorities living in the area, who were found to require firewood as a primary resource. Firewood consumption was greatest among the Thai minority families (187.62 kg/household/month), followed by the Muong and Mong minorities (112.61 and 101.96 $\mathrm{kg} /$ household/month, respectively). Economic development was the most important factor in the demand for firewood because of consumption for household businesses. An important finding from this research was that the respondents indicated that rangers did not patrol frequently nor did they strictly enforce the regulations prohibiting the collection of firewood. A well-managed firewood resource could support minority households' requirements, improve fire-efficiency, and contribute to natural reserve objectives through ranger's efforts.
\end{abstract}

Keywords: firewood consumption, ethnic minority, household, patrol, rangers, reserve

\section{Introduction}

Since the time a human lit the very first fire, biomass resources have contributed to providing energy for millions of people (Kimemia and Annegarn, 2011). Particularly, in developing countries, forest resources are intensively used by remote communities, even inside nature reserves, and play important roles in their livelihoods (Kumar and Shahabuddin, 2005; Kim et al., 2016). Forest extraction, including timber, hunting, firewood, and grazing, either for direct use or business, has been regarded as a critical issue confronted by management in protecting forest resources (Hegde and Enters, 2000). Sources of firewood are one of society's oldest requirements (Lindroos, 2011), and a vital source of household energy in rural areas essential in the preparation of many staple foods (Biran et al., 2004; Mon et al., 2012). The reality of demands for 
traditional biomass in the form of firewood from forest resources is and will continue to be crucial for energy management and for ethnic people (Ektvedt, 2011; Maes and Verbist, 2012) and pressure on forests due to the continuous loss of biomass will also continue (Chettri et al., 2002).

Forests are one of the most important sources of firewood (Sassen et al., 2015) and are the main and the most frequently used energy source in remote areas in developing and poor countries (Kim et al., 2016; Reyes et al., 2018). Nearly 3 billion people continue to use fuelwood in their daily lives (He et al., 2009) as the first choice of energy for cooking and heating rooms (Felix, 2015) and it is also used for heating water or conducting traditional businesses within households (Nyambane et al., 2014; Wang et al., 2015; Schueftan et al., 2016). However, the distribution of forest resources for traditional use as fuelwood is increasingly affecting biodiversity and decreasing forest cover (Maes and Verbist, 2012). Sassen et al. (2015) found that the amount of dead wood or resident natural forest was affected by fuelwood collection for up to $1000 \mathrm{~m}$ inside the boundary of parks in upland Uganda and local villagers who live near to protected tropical forests particularly depend on those forests as their primary source of firewood.

Similarly, in Vietnam, most households depend on firewood to satisfy their demand for energy. Firewood is collected from farms, community and private forests, and private plantations as either live or dead wood (Nyambane et al., 2014) where tree byproducts such as pruned branches from bamboo plantations, agricultural waste, and dry plantation wood are collected (Nyambane et al., 2014). Firewood, in Vietnam and other countries is considered as being a free commodity, which may be collected without cost other than that associated with the gatherer's own personal efforts (Kim et al., 2016). In the buffer zone of $\mathrm{Pu} \mathrm{Hu}$ nature reserve (NR), the collection of firewood is strictly regulated through restrictions on wood-cutting (Nyambane et al., 2014). The scale of the households' requirement for and use of firewood is a critical issue that confronts forest management (Wang et al., 2015). This is particularly critical in mountainous regions, where limited energy sources lead to high pressure on scarce natural resources (Rantala et al., 2004; Mislimshoeva et al., 2014).

People's requirement for firewood as a basic source of energy is causing serious deforestation problems in various developing countries (Fox, 1984). The increased demand for firewood threatens the habitat of many wildlife species (Carey and Gill, 1980) in protected areas, and there is a need for an improved understanding of the use of the resource to enable conservation strategies to be better adapted to local livelihoods (Abbot and Mace, 1999). Ormsby and Kaplin (2005) found that even though residents were mostly aware of a NR's existence they were unfamiliar with its goals resulting in a problematic relationship between NRs and human communities \{Formatting Citation\}. This means that even with increased time devoted to patrolling or more severe penalties, law enforcement practice alone is unlikely to safeguard protected areas because there are no alternative supplies of firewood which can be used by local people (Abbot and Mace, 1999).

There have been few studies of firewood consumption conducted in Vietnam. The FAO (2017) reported that the firewood and energy sectors were estimated to have extracted around 5 million tons of fuelwood in 2016 consisting of charcoal, chips, residues, and pellets. The daily firewood demand for traditional pig production in Hue province has also been estimated to lie somewhere between 6.1 and $21.3 \mathrm{~kg}$ (Lan et al., 2002; Kien and Harwood, 2017). 
Wasted agricultural residues are a very abundant source of biomass (Tung, 2009) and are traditionally burned as firewood as a source of energy in Vietnam (Khoa et al., 1999). Nonetheless, available data on firewood consumption in different areas in Vietnam is lacking (Kim et al., 2016), and there has been relatively little research attention devoted to the assessment of firewood use for daily needs in the buffer zone of $\mathrm{Pu} \mathrm{Hu} \mathrm{NR}$. In fact, there is little information available regarding firewood extraction and use by minority $\mathrm{n}$ the buffer zone of the protected area around the NR, or in Vietnam generally. Firewood extraction by ethnic minorities may be having an impact on conservation on the area studied in the research described in this paper. Moreover, the effects of firewood collection and law enforcement practices related to natural resources are frequently not fully investigated nor understood (Brown et al., 2009)

To gain a better understanding relating to these issues, research was conducted on firewood extraction in the buffer zone of $\mathrm{Pu} \mathrm{Hu} \mathrm{NR}$, Vietnam. The aims of this study were to identify (1) different forms of firewood consumption based on location and ethnic minority; and (2) to foster cooperation between ethnic minority households and NR rangers. The final objective was to support forest management's efforts to adjust their law enforcement practices to take into account ethnic minority households' demands for forest resources.

\section{Materials and methods}

\section{Research site}

$\mathrm{Pu} \mathrm{Hu} \mathrm{NR}$, located in Quan Hoa and Muong Lat districts in Thanh Hoa province in northeast Vietnam, was established in 1999 as a NR by the government of Vietnam and is one of the largest in this province covering around 28.000 ha. It is managed by the $\mathrm{Pu} \mathrm{Hu}$ management board in Quan Hoa district and is located in a mountainous area (latitude $20^{\circ} 30^{\prime}$ to $20^{\circ} 40^{\prime} \mathrm{N}$ and longitude $104^{\circ} 40^{\prime}$ to $105^{\circ} 05^{\prime} \mathrm{E}$ ) (Fig. 1). It is home to a number of endangered animals, and rare plant species. Following the establishment of the NR, all extraction activity by people living in the area of the NR was made illegal. However, even after the NR was established, the extraction of folder and fuelwood has been informally allowed although people are not allowed to enter the NR without official permission. Communities living around $\mathrm{Pu} \mathrm{Hu}$ NR practice subsistence farming based on the cultivation of crops and supplement those crops by the exploitation of non-timber forest production (NTFPs), raising livestock and by the cultivation of bamboo (Thapa and Chapman, 2010). The biggest management issues include the relatively unrestricted extraction of forest resources by local residents from the surrounding area (Allendorf and Allendorf, 2012). The major forest resource use focused on in this case study is the requirement for firewood as a source of energy for the ethnic minority households in the area..

This study was conducted during the cold season, extending from November 2017 to March 2018 in the buffer zone of the Pu Hu NR, where there are 24,569 residents in 5,694 households living in 61 villages in 11 communes in two districts (Muong Lat and Quan Hoa). Most local people practice farming, cultivating crops such as paddy, maize, manioc, and vegetables. There has also some forestry activities including the extraction of both timber and non-timber products. Other occupations include harvesting bamboo, retailing and working as hired labor. 


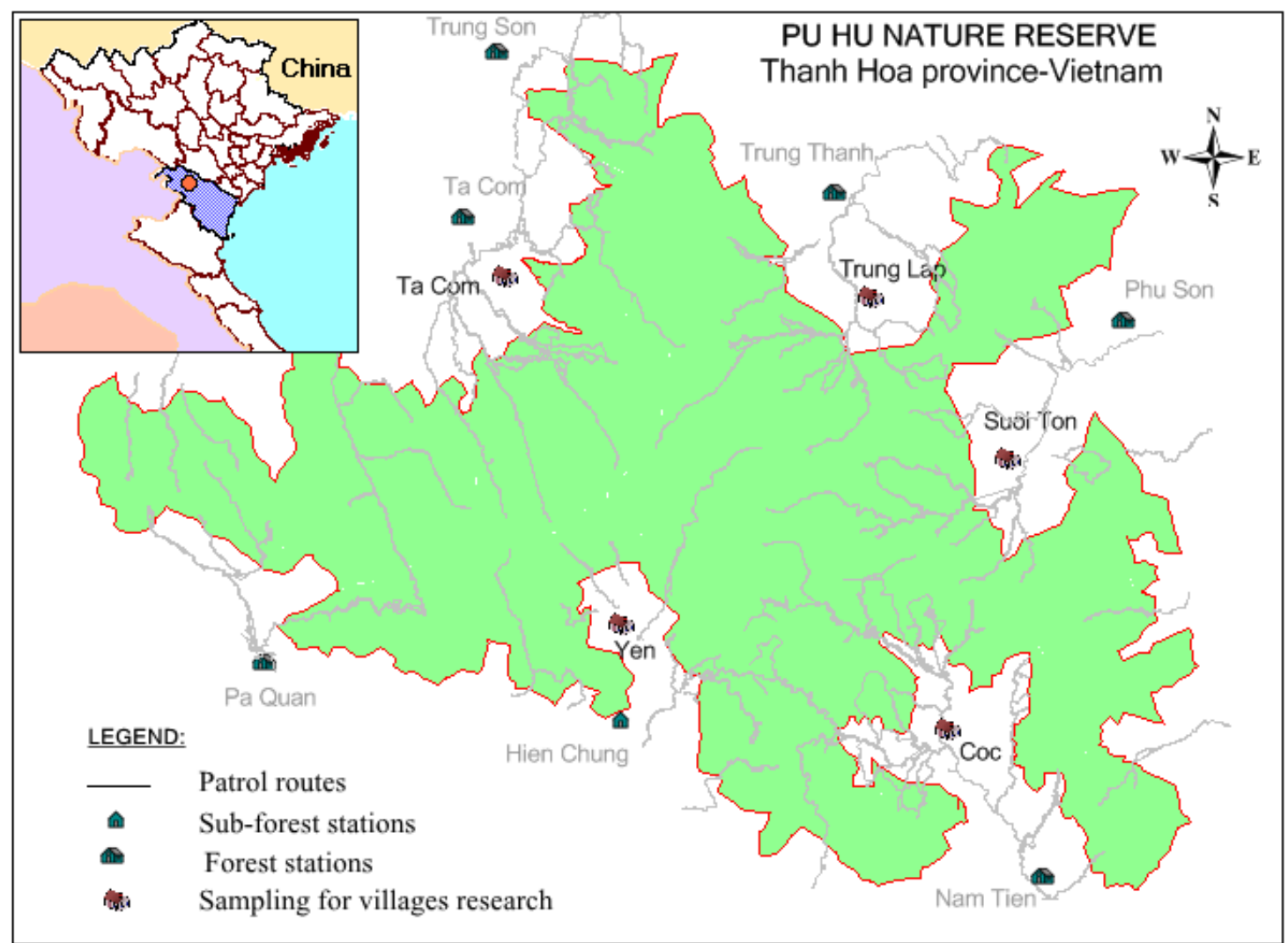

Figure 1. The location of case study of $\mathrm{Pu} H \mathrm{H}$ NR

\section{Data collection}

Data on firewood use was collected in fieldwork using a questionnaire, observation and face-to-face interviews between November 2017 and February 2018. For the buffer zone of $\mathrm{Pu} \mathrm{Hu}$, over $90 \%$ of the households from different minorities in 5 villages in 5 communes were sampled and interviewed as well as being observed in their daily firewood collecting activity. Household surveys and Interviews were carried out in between 40 and 80 households per village and were conducted either by one of the researchers or by the village leader, based on visiting each household. By preference the head of each family was interviewed, who either completed the questionnaire or answered the questions asked by the interviewer, the answers to which were then filled in on the questionnaire by the interviewer. In most cases the head of household was male and it was a more difficult to interview women among the ethnic minorities because they were mostly illiterate or felt ashamed at being asked questions. If the head of the household was not available a willing member of the household was selected (Thapa and Chapman, 2010). Before the interviews took place there was a meeting in the village with a head of the village who was a key-informant, to gain an understanding of the background of changes. It had taken place in the area in the past as well as obtaining background information on socio-economic conditions, village size, and the distribution and number of households and the size of their families, and a list of households was obtained.

The researcher also interviewed a number of $\mathrm{Pu} \mathrm{Hu} \mathrm{NR}$ rangers in order to gain an understanding of the situation regarding the collecting of firewood, and to gain an 
understanding the law enforcement regime relating to firewood collection in the buffer zone, as well as to discuss the government's firewood programme.

The questionnaire was formulated in English then translated into Vietnamese (SousaSilva et al., 2016) and consisted of a mixture of open-ended and closed-ended questions in three parts: the first relating to the respondent's socio-economic situation (Table 1), the second to establish the household's requirement for firewood, and the third to gain an understanding of the household's perspective relating to the NR rangers' activities.

Table 1. Description of socio-economic aspects from survey

\begin{tabular}{|c|c|c|}
\hline $\begin{array}{l}\text { Social-economic } \\
\text { parameter }\end{array}$ & Classification & Description \\
\hline $\begin{array}{c}\text { Gender } \\
\text { Age (years) } \\
\text { House size } \\
\text { Number of families }\end{array}$ & & \\
\hline $\begin{array}{l}\text { Household income } \\
\quad \text { (per month) }\end{array}$ & $\begin{array}{l}\text { Wealthy } \\
\text { Average } \\
\text { Close to poor } \\
\text { Poor }\end{array}$ & $\begin{array}{l}(\geq 76 \text { USD) } \\
(51-75 \text { USD) } \\
(31-50 \text { USD) } \\
(\leq 30 \text { USD) }\end{array}$ \\
\hline $\begin{array}{l}\text { Education level of the } \\
\text { leader of household }\end{array}$ & $\begin{array}{c}\text { Tertiary education } \\
\text { High school } \\
\text { Secondary school } \\
\text { Primary school } \\
\text { No formal education }\end{array}$ & $\begin{array}{c}\text { Upper } 12 \text { years of education } \\
10-12 \text { years of education in high school } \\
6-9 \text { years of education in secondary school } \\
1-5 \text { years of education in primary school } \\
\text { Not educated in school }\end{array}$ \\
\hline $\begin{array}{l}\text { Occupation of person } \\
\text { interviewed in household }\end{array}$ & $\begin{array}{l}\text { Full-time farming } \\
\text { Part-time farming }\end{array}$ & $\begin{array}{l}\text { Working in the field all the time } \\
\text { Doing some other job in addition }\end{array}$ \\
\hline
\end{tabular}

\section{Data analysis}

Data relating to the households' income levels, firewood use, and the purposes for which firewood was used by the households in the selected villages were collected from interviews. Data on the firewood consumption situation by the different ethnic minority households were summed and averages and percentages for each minority were computed (Kim et al., 2016). Data analysis was performed using the SPSS version 20 software package and Microsoft Excel. Both descriptive and statistical data analyses were performed. The calculation of sample means, standard errors, medians, minimum and maximum values, and frequency distributions was conducted.

Inferential statistical analysis was used to discover the relationships among the relevant variables. Because the data was not normally distributed, the Mann-Whitney U test for two variables and the Kruskal-Wallis test for more than two variables were used in SPSS, to analyze the data with any significant differences expressed at the 0.05 level (or higher where indicated in the text). The estimated volume of firewood consumed by the three ethnic minorities in the five villages was computed based on the data from the questionnaires. 


\section{Results}

\section{Background information established from the survey of households}

Three-quarters of the 248 interviewees $(75 \%)$ were male and the age of the interviewees ranged from 20 to 75 years with the median age, 36 years (Table 2). the largest age group, represented was 20-35 years with $48 \%$ of the respondents. The average house size was $144.6 \mathrm{~m}^{2}$, varying between 23 and $450 \mathrm{~m}^{2}$ and more than half the houses $(54 \%)$ were below $100 \mathrm{~m}^{2}$. The mean number of persons in each household was five, ranging from 3 to 12 members and more than half of the households $(56.5 \%)$ had between five and eight persons. Regarding the income situation of the households, around $64 \%$ fell within the poor level, whilst those close to poor or with an average living standard accounted for 19.4 and $7.7 \%$ of the households surveyed, respectively. More than half of the interviewees in the households $(57.3 \%)$ had had secondary school level education (five years and four years of education in the primary school and secondary school, respectively). Based on occupation, $87.9 \%$ of the interviewees in the households were full-time farmers.

Table 2. Summary of socio-economic respondents based on the survey

\begin{tabular}{|c|c|c|c|}
\hline Social-economic situation & Categories & Frequency (n) & Proportion (\%) \\
\hline \multirow{2}{*}{ Gender } & Male & 186 & 75.0 \\
\hline & Female & 62 & 25.0 \\
\hline \multirow{4}{*}{ Age (years) } & $20-35$ & 118 & 47.6 \\
\hline & $36-50$ & 95 & 38.6 \\
\hline & $51-65$ & 29 & 11.7 \\
\hline & $66-75$ & 6 & 2.4 \\
\hline \multirow{4}{*}{ House size } & $\leq 100$ & 135 & 54.4 \\
\hline & $101-200$ & 65 & 26.2 \\
\hline & $201-300$ & 29 & 11.7 \\
\hline & $\geq 301$ & 19 & 7.7 \\
\hline \multirow{3}{*}{ Number of persons } & $\leq 4$ & 108 & 43.5 \\
\hline & $5-7$ & 120 & 48.4 \\
\hline & $\geq 8$ & 20 & 8.1 \\
\hline \multirow{4}{*}{ Household income (per month) } & Wealthy & 22 & 8.9 \\
\hline & Average & 19 & 7.7 \\
\hline & Close to poor & 48 & 19.4 \\
\hline & Poor & 159 & 64.1 \\
\hline \multirow{5}{*}{$\begin{array}{c}\text { Education level of the leader of } \\
\text { household }\end{array}$} & Tertiary education & 1 & 0.4 \\
\hline & High school & 22 & 8.9 \\
\hline & Secondary school & 142 & 57.3 \\
\hline & Primary school & 69 & 27.8 \\
\hline & No formal education & 14 & 5.6 \\
\hline \multirow{2}{*}{$\begin{array}{c}\text { Occupation of person interviewed in } \\
\text { household }\end{array}$} & Full-time farmer & 218 & 87.9 \\
\hline & Part-time farmer & 30 & 12.1 \\
\hline
\end{tabular}




$$
-4235 \text { - }
$$

There were significant differences in socio-economic conditions among the household in the $\mathrm{Pu} \mathrm{Hu}$ buffer zone with income earned by the three ethnic minorities different, at the $p<0.001$ level. The Thai ethnic minority earned the highest average net annual income of $64.67 \pm 51.80 \mathrm{USD} /$ person/month, while the lowest income was $21.98 \pm 12.33 \mathrm{USD} /$ person/month for the Mong minority. Further, there were moderately low but significant correlations between the socio-economic data and firewood consumption. The total amount of firewood used was correlated with housesize, number of persons, and income based on Spearman rank order correlations ( $\mathrm{rs}$ ) of $0.24,(\mathrm{p}<0.01), 0.24(\mathrm{p}<0.01)$ and $0.30(\mathrm{p}<0.01)$ respectively for the communities.

\section{Location of firewood collection areas for daily use}

All the ethnic minority households used firewood baskets carried as headloads as illustrated in Figure 2, and they frequently carried large loads supported by both their backs and heads as reported by Sassen et al. (2015) in research in protected areas in Uganda. Additionally, $65 \%$ of the respondents transported firewood-using motorbikes, and some households also used bicycles.

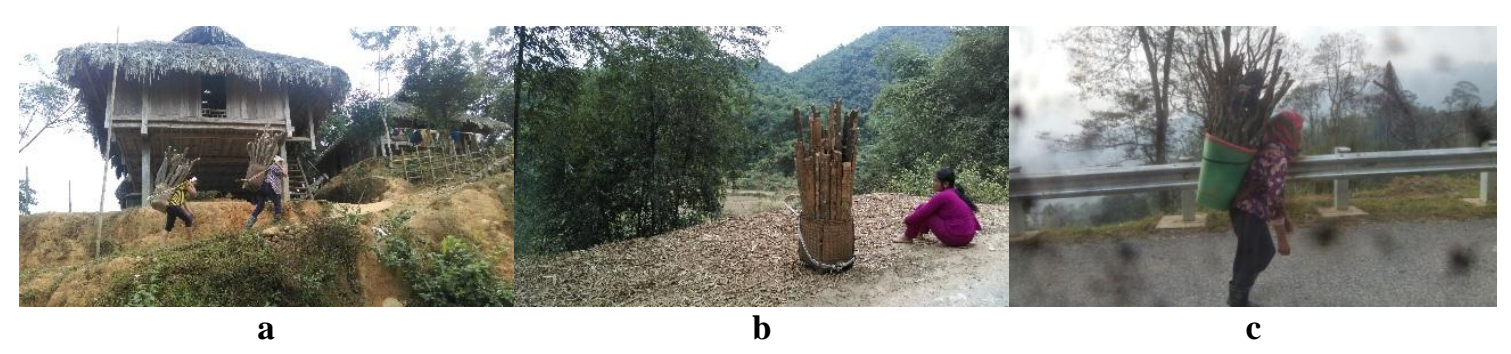

Figure 2. Photographs of typical headloads in the field (a) Muong; (b) Thai; (c) Mong. (Source: Pu Hu NR and author)

When asked about the main natural forest resources used by their household, all the respondents stated that their family as a source of energy used firewood daily. Of the respondent households, 74 and 163 were involved in harvesting timber and NTFP respectively. There were three sources of firewood collected as a daily activity: $\mathrm{Pu} \mathrm{Hu}$ NR, private forest, and agricultural land. The three minorities mainly collected firewood in forestland (Mong: 28\%, Muong: 12\% and Thai 18\%; see Fig. 3). In the Pu Hu NR, the Mong minority was the main group who collected firewood accounting for about $10 \%$ of the firewood they extracted (Fig. 3), while the percentage of firewood collected by other minorities was less than $2 \%$.

Furthermore, for daily cooking and boiling water as shown in Table 3, the Thai ethnic minority households required the greatest amount of firewood $(36.02 \pm 10.08 \mathrm{~kg})$ while the Mong and Muong minorities used less for these purposes (31.51 \pm 17.25 and $22.57 \pm 11.59 \mathrm{~kg}$, respectively). Similarly, the amount of firewood used for heating was significantly different among the ethnic minorities (Table 3; Fig. 4). The amount of firewood used by the Thai minority $(21.00 \pm 11.54 \mathrm{~kg})$ was nearly double that used by the Mong minority $(12.88 \pm 4.34 \mathrm{~kg})$ with the Muong minority being the second highest $(15.01 \pm 7.80 \mathrm{~kg})$. The average firewood used for this purpose was $15.17 \pm 7.97 \mathrm{~kg} / \mathrm{month} /$ household.

There was a significant difference in the monthly amount of firewood used for livestock, with the lowest mean firewood consumed for this purpose of 


$$
-4236-
$$

$26.48 \pm 18.27 \mathrm{~kg} / \mathrm{month} / \mathrm{household} \mathrm{being} \mathrm{found} \mathrm{in} \mathrm{the} \mathrm{Mong} \mathrm{minority.} \mathrm{It} \mathrm{was} \mathrm{only}$ around a third and a fifth that used by the Muong and Thai minorities, respectively, even though only $75 \%$ of the Muong households used firewood for livestock whereas all the Mong households used firewood for that purpose. The mean amount of firewood used by all three ethnic minorities for their livestock was $63.17 \pm 48.26 \mathrm{~kg} /$ day/household.

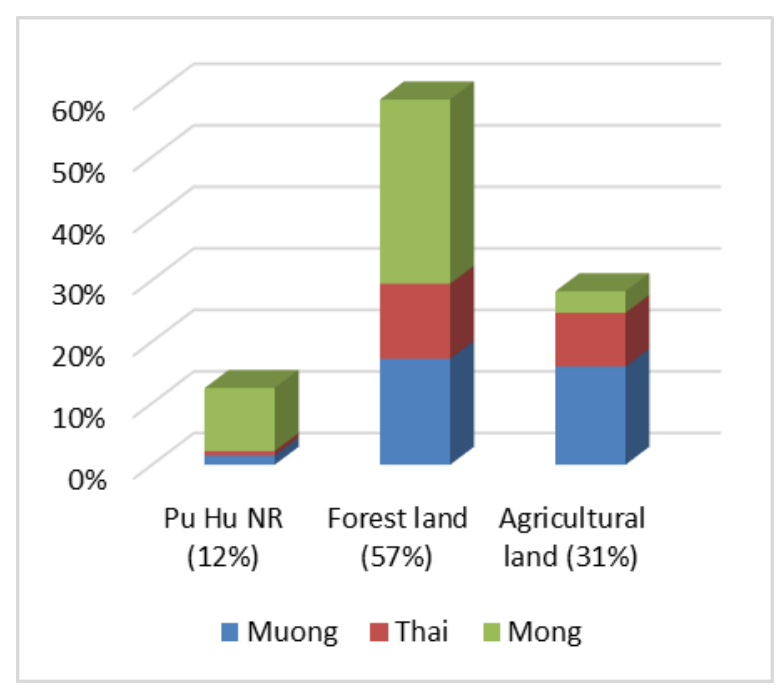

Figure 3. Location of firewood collection by three-ethnic minority households (\%)

Table 3. Percentage of households using firewood for different purposes and mean monthly volume consumed

\begin{tabular}{c|c|c}
\hline $\begin{array}{c}\text { Category of firewood use by } \\
\text { ethnic minority }\end{array}$ & $\begin{array}{c}\text { Percentage of households interviewed } \\
\text { using firewood for this purpose }\end{array}$ & $\begin{array}{c}\text { Mean monthly volume } \\
\text { (kg/household) }\end{array}$ \\
\hline $\begin{array}{c}\text { Cooking and boiling water } \\
\text { Muong }\end{array}$ & $100 \%$ & $22.57 \pm 11.59$ \\
Thai & $100 \%$ & $36.02 \pm 10.08$ \\
Mong & $100 \%$ & $31.51 \pm 17.25$ \\
\hline Heating & $91 \%$ & $15.01 \pm 7.80$ \\
Muong & $94 \%$ & $21.00 \pm 11.54$ \\
Thai & $100 \%$ & $12.88 \pm 4.34$ \\
Mong & $75 \%$ & $87.07 \pm 31.00$ \\
\hline Livestock & $94 \%$ & $125.22 \pm 31.49$ \\
Muong & $100 \%$ & $26.48 \pm 18.27$ \\
Thai & & $18.31 \pm 10.49$ \\
Mong & $36 \%$ & $34.53 \pm 26.91$ \\
\hline Making wine & $29 \%$ & $31.37 \pm 8.57$ \\
Muong & $99 \%$ & $24.64 \pm 18.24$ \\
Thai & $18 \%$ & $40.00 \pm 12.25$ \\
Mong & $10 \%$ & \\
\hline Bamboo drying & Not used & \\
Muong & & \\
Thai & & \\
Mong & &
\end{tabular}



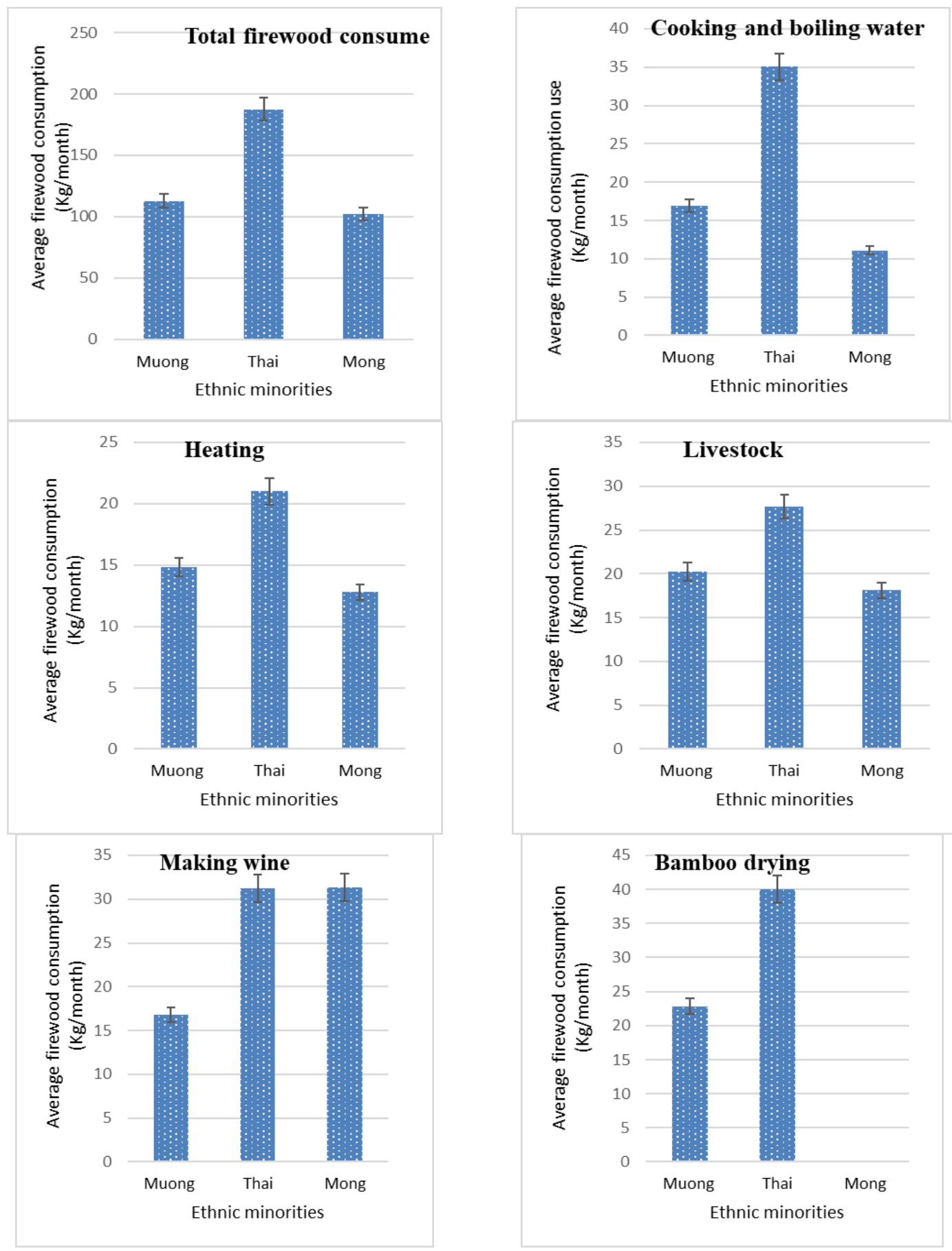

Figure 4. The estimated monthly weight of firewood used in total and for different purposes

Further, the Thai minority households used a significantly higher monthly amount of firewood for making wine $(34.53 \pm 26.91 \mathrm{~kg})$ than the Mong minority $(31.37 \pm 8.57)$, whereas the Muong households used only around half the amount used by Thai households for that purpose. Moreover, only around 30\% of the Muong Thai households used firewood for this purpose and the number was more than three times that among the Mong households. The average firewood used for this purpose was $29.48 \pm 12.71 \mathrm{~kg} / \mathrm{month} /$ household. 


$$
-4238 \text { - }
$$

It was found that none of the Mong households used firewood for drying bamboo but almost twice as many Muong households used firewood for this purpose than Thai households. Nevertheless, the amount of firewood used in the Thai households $(40.00 \pm 12.25 \mathrm{~kg})$ was higher than that used in the Muong households $(24.64 \pm 18.24 \mathrm{~kg})$ with the average firewood used for drying bamboo being $28.68 \pm 17.94 \mathrm{~kg} / \mathrm{month} /$ day.

The average firewood used by the three ethnic minorities combined was $123.19 \pm 60.49 \mathrm{~kg} / \mathrm{month} /$ household. However, the Thai households consumed the highest amount of firewood per month $(187.62 \pm 67.23 \mathrm{~kg})$, while the Muong and Mong households consumed broadly similar amounts of firewood $(112.61 \pm 58.03$ and $101.97 \pm 34.57 \mathrm{~kg}$, respectively - see Fig. 4). Furthermore, the use of firewood by the Thai households for all purposes of daily living was the highest among the three ethnic minority households. However, the amount of firewood used for heating, livestock and bamboo drying in the Muong households was higher than that of the Mong households and overall, the monthly firewood used by each household among the three minorities was significantly different $(\mathrm{H}=67.06 ; \mathrm{p}<0.01)$ as was the personal firewood consumption $(\mathrm{H}=20.82 ; \mathrm{p}<0.01)$.

Interestingly, averaging the observed November to February consumption rates and extrapolating from that across the total number of individuals (i.e., $30 \mathrm{~kg} /$ person $\times 12$ months). The approximately $360 \mathrm{~kg}$ per person of firewood is consumed by the Muong minority during a year while the firewood used by the Thai and Mong minorities was lower at $324 \mathrm{~kg} /$ year and $240 \mathrm{~kg} / \mathrm{year}$.

\section{Ranger activity in the villages}

When interviewed, nearly half the Muong and $72 \%$ of the Mong said that they occasionally saw rangers patrolling whereas about $65 \%$ of the Thai minority interviewed said that they sometimes met rangers patrolling (Fig. 5). Interestingly, a very low percentage of Muong people (1\%) generally met rangers while collecting firewood while nobody in the other ethnic minorities generally saw rangers patrolling. When asked what happened when they met a ranger, the main proportion experienced being talked to by the ranger (Muong 55\%, Thai 49\%, and Mong 85\%). The rangers rarely, arrested people in the three ethnic minorities with only $2 \%$ of the Thai people reporting having been arrested.

Figure 6 details the communication between the minority households and local rangers with the main percentage $(58 \%)$ of Muong and Mong households having had communication with rangers, but $67 \%$ of the respondents in Thai households having no communication with rangers (Fig. 6). Interestingly, the quality of advice from the rangers reported by almost all the Thais (94\%) was normal while the percentage of 'normal' advice to the Mong (48\%) and Muong (45\%) was lower.

There were similar percentages of the three minorities who considered that the rangers provide technical support for forest development. But the percentages of Mong and Thai who considered forest policy to be appropriate (70\% and $50 \%$, respectively) was higher than that among the Muong households, many of whom (62\%) suggested that the rangers should come to their villages regularly (Fig. 7). With regard to the improvement of forest development, the largest number of Muong and Thai households wanted support for forest activities (58\% and 62\%, respectively, while most Mong households felt that the best way to improve forest development was by the selection of good village leaders. 

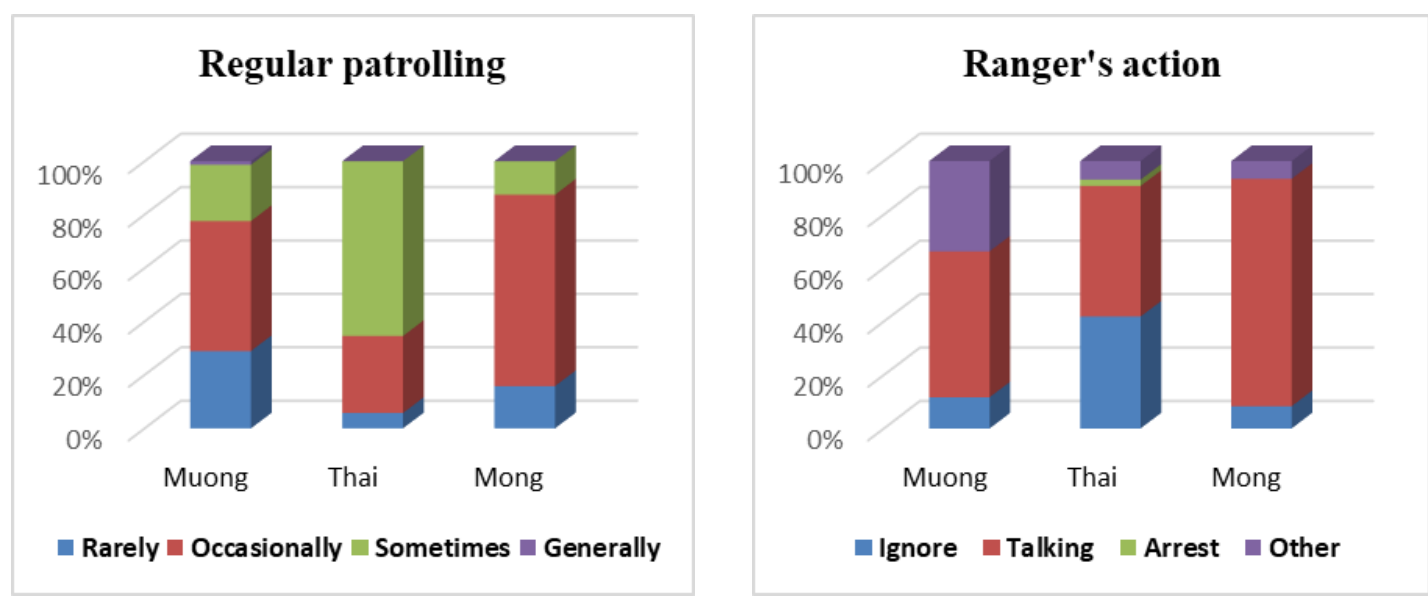

Figure 5. Ranger's patrolling and action when meeting firewood collectors
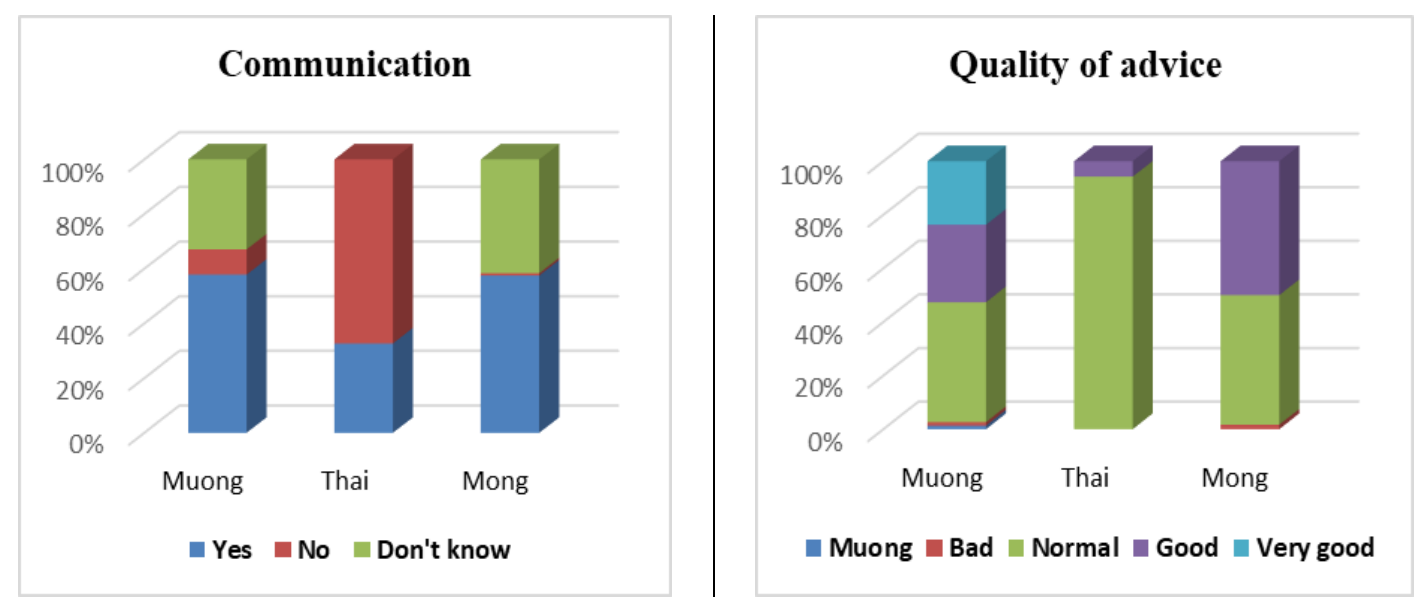

Figure 6. Communication with and quality of advice from rangers
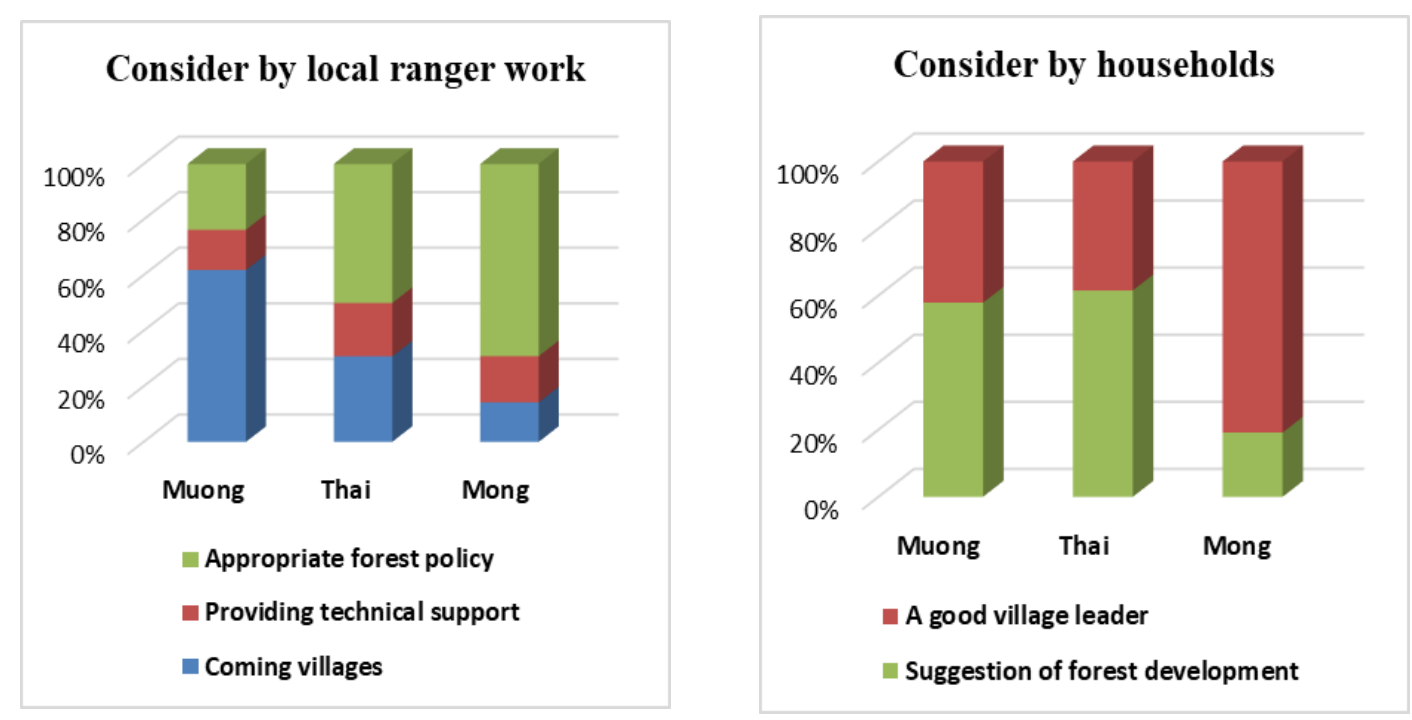

Figure 7. Households' opinions about improving ranger's roles and forest development 


\section{Discussion}

\section{Firewood use relative to social aspects}

Firewood was found to be the main energy source for residents in the $\mathrm{Pu} \mathrm{Hu}$ buffer zone and is likely to remain an important natural resource because it is essential for human activity (Wangchuk et al., 2014). Overall, the firewood consumed by the three ethnic minorities was significantly correlated with households' economic indicators, house-size, and the number of persons in the family (Démurger and Fournier, 2011; Wang et al., 2015). It was found that all the households had forest land and agricultural land, and almost all the households conducted farming as their daily activity. The forest land which makes up the core zone of the NR is far from the area occupied by the households and thus the collection of firewood is difficult and time-consuming and is mainly carried out by the women in the family (Abbot and Mace, 1999; Maes and Verbist, 2012; Tabuti et al., 2003). This study showed that the household size based on the number members of the family had a relationship with the firewood used and this finding was similar to the results of previous studies (Marquez-Reynoso et al., 2017; Win et al., 2018).

\section{Firewood collection and requirement}

In the present work, it was found that firewood is a vital resource in the villages adjacent to the $\mathrm{Pu} \mathrm{Hu}$ buffer zone (Cardoso et al., 2013). The requirement for firewood is more common, compared to timber and NTFP because firewood is used as the major fuel (Kim et al., 2016). Firewood collection on forest land appears to be more intense than in agricultural land in the region as previously found by Sassen et al. (2015) in the forest of Mt Elgon National Park (Uganda) and the implementing of a buffer zone is a way to reduce some of the pressure on NRs (Naughton-Treves et al., 2007). However, local people (nearly $70 \%$ ) mainly collected firewood from the forest areas including in forestland both inside and adjacent to the NR. This activity puts pressure on forest resources and is likely to lead to serious deforestation (Fox, 1984; Agurto Adrianzén, 2013). In Pu Hu NR, the percentage of household firewood collected in the NR used by the Mong (about 10\%) was the highest among the three minorities. Even though $\mathrm{Pu} \mathrm{Hu}$ NR is a protected area it makes a highly important contribution to the livelihood of households in the area as similarly found by Kim et al. (2016) in considering Ke Go NR in Vietnam. Moreover, as found by Thapa and Chapman (2010) who conducted research in Bardia National Park, Nepal when farming areas and the collection of resources is very important, local people may not be deterred by measures to deter them from using a protected area. However, the study conducted in Indonesia by Pattanayak et al. (2004) reported that households extracted firewood from a local NR forest and their own fields. To collect firewood in the NR, individuals interviewed in this study said people walked over $2 \mathrm{~km}$ taking from $3 \mathrm{~h}$ to half of the day to cut and collect a full head-load of wood (Win et al., 2018). The distance between households and the protected areas is a challenge and discouraged most local people from entering the NR to harvest firewood.

The estimated yearly quantities of firewood consumed were around $300 \mathrm{~kg}$ per household among the three ethnic minorities living in the $\mathrm{Pu} \mathrm{Hu}$ buffer zone which was very similar to the household requirement in the Budongo Forest Reserve, Uganda of $316 \mathrm{~kg}$ firewood (Tweheyo et al., 2005). Mislimshoeva et al. (2014) found a per household consumption of $355 \mathrm{~kg}$ year in the Western Pamirs and Bhatt and Sachan 
(2004) suggested that $174 \mathrm{~kg}$ of firewood was used per year by each household in communities in northeast India. Further, Kim et al. (2016) reported a consumption of about $165 \mathrm{~kg}$ per household in the neighbouring province of Nghe An.

Firewood use was highest among the Muong minority $(1.03 \mathrm{~kg} / \mathrm{capita} / \mathrm{day})$, followed by the Thais $(0.89 \mathrm{~kg} /$ capita/day) and Mong ( $0.67 \mathrm{~kg} /$ capita/day), irrespective of their socio-economic status. Comparatively more firewood is used by tribal minorities in Arunachal Pradesh and Garos in northeast India with 3.1 and $5.0 \mathrm{~kg} / \mathrm{capita} / \mathrm{day}$, respectively (Maikhuri, 1991). Sassen et al. (2015) found that people consumed an average of between 2.14 and $3.88 \mathrm{~kg}$ of fuel-wood per capita per year in Mount Elgon national park in Uganda.

In common with the present study, Victor and Victor (2002) and Kim et al. (2016) reported that the average firewood consumption was highest for business activities such as raising livestock. The Thai and Muong minorities are more focused on developing their economic status, and therefore their requirement for firewood was found to be higher for this purpose than for others in similar research conducted in Vietnam by Kim et al. (2016). The livestock business plays a crucial role in household income structure and pig and cattle raising is important to the livelihoods of various minorities living in rural areas (Kim et al., 2016). Based on economic development, the Mong minority generally had lower household incomes, and therefore their priority use of firewood was for cooking and boiling water. Moreover, the Mong people also live in more inaccessible and higher areas than the Thai and Muong minorities.

\section{Connection between households and forest rangers}

It is undeniable that firewood is important for a sustainable livelihood among rural people without access to other sources of energy (Kimemia and Annegarn, 2011). Households among the ethnic minorities in the Pu Hu buffer zone mainly used firewood as their source of energy and the main areas for collecting firewood are the forest and agricultural land which are accessible to everybody in the adjacent villages (Kim et al., 2016). Thus, It seems that firewood will remain an important source of energy for the ethnic minority households (Nansaior et al., 2011). Law enforcement is inefficient because the number of effective patrol days is low compared with the potential number of scout working days as reported by Bell and Mcshane-Calzi (1986). A different situation was found by Sassen et al. (2015) in Uganda, where the official allowance per household under forest protection agreements was one headload, twice per week. However, in this study it was observed that although officially excluded, local people have been permitted to collect firewood from the NR area. Rangers at Pu Hu NR said that firewood was collected from both inside the NR and from adjacent forestland, but that they do not consider this a major issue because the volume of firewood taken is not great. This finding is in agreement with those of Kimemia and Annegarn (2011) and Abbot and Mace (1999) in studies in South Africa and Lake Malawi National Park, respectively. Based on the reports of the minority Muong and Mong they patrolling efforts are sporadic and when they encountered the rangers while collecting firewood they would talk to the farmers rather than arresting them.

Most of the respondents considered that the quality of the rangers' advice was normal and there was communication between rangers and some of the people in all three ethnic minorities. Effective communication is necessary because this enables a flow of helpful information about the forest and its management, which is necessary to formulate the authority's management policy (Wang et al., 2015). Insufficient 
communication between rangers and local people might cause negative behavior related to illegal activity inside and outside the NR (Obua et al., 1998). It is notable that more than half of the Muong minority community interviewed expressed the view that the rangers should conduct regularly patrols in their villages, while most of the Mong minority considered it more important for the rangers to implement appropriate forest policy. Due to improvement of forest management, around $80 \%$ of Mong respondents focused on having a good village leader, whereas the other ethnic minorities both indicated that the forest development policy was more important

\section{Conclusion}

Forests are still a major source of firewood for ethnic minority households in $\mathrm{Pu} \mathrm{Hu}$ buffer zone and provide them with substantial economic benefits (Wangchuk et al., 2014). In this study, the patterns of household firewood use were analyzed for the three minorities in the Pu Hu buffer zone, namely the Muong, the Thai and the Mong, using primary data obtained during research in villages located adjacent to the $\mathrm{Pu} \mathrm{Hu} \mathrm{NR}$. The paper also analyzed the relevant factors that influence household firewood consumption, including the number of household members, and house-size. A comparison by way of a descriptive analysis of households of the three minorities was presented and their firewood requirements were established as being the major demand which they make of local natural resources (Behera et al., 2015). In the study location, the Thai minority households tended to consume more firewood than other minorities. However, the percentage of firewood collected by the Mong households in the nature reserve was the greatest among the three minorities and whilst the Thai minority constitute the largest ethnic group, it is the Mong minority who have the traditional culture of collecting firewood in $\mathrm{Pu} \mathrm{Hu} \mathrm{NR}$. Thus, NR rangers had to talk to them and demand that they reduce their collection of firewood in the NR when they met them while patrolling. In view of this situation, the management of the NR should focus on the firewood needs of the Mong households, for instance by improving their knowledge of forest protection, enhancing reforestation, reducing the risk of forest fires, and contributing to conservation (Wangchuk et al., 2014).

In the long-term, the best way of dealing with this problem would be to provide greater subsidies for the use of electric power for personal consumers, as a way of reducing pressure on the forests in buffer zone (Naughton-Treves et al., 2007). In the short-term, it is suggested that the widespread introduction of improved-design cooking stoves (both in terms of firing efficiency and heating conductibility) to replace the traditional three-stone cooking rings used by local people, is pursued as a matter of urgency (Kim et al., 2016). On the other hand, rangers should regularly patrol and carry out their responsibility of forest protection, even though in practice, there is little extraction of firewood from the NR. To enhance the sustainable management of resources, firewood harvesting by minorities could be controlled by rangers in this location as part of their duty to ensure that it is carried out in a manner that does not create ecological impacts. Moreover, the park management should convince villagers to find ways of working without resorting to illegal resource extraction, which in the long term would be the best way of preventing ecological damage in the Pu Hu NR (Thapa and Chapman, 2010). Further, upcoming research should consider on patrolling rangers efforts in each location that could be influent local's behavior and firewood collection. 


$$
-4243 \text { - }
$$

Acknowledgements. We would like to thank Thailand's Education Hub for Southern Region of ASEAN Countries (TEH-AC), the Graduate School of Sustainable Energy Management, and the Faculty of Environmental Management of Prince of Songkla University, Thailand for supporting this research. We are grateful to the local people in the households of the three ethnic minorities in the $\mathrm{Pu} \mathrm{Hu}$ buffer zone for assistance in the field and for contributing and sharing their knowledge about firewood consumption. Further, we greatly appreciate the help of the rangers in all the forest stations and the Department of Science and International Cooperation in the Pu Hu NR for their support, advice and assistance during the field survey. Mostly, we would like to thank Mr. Le Khac Dong who fully designed, analyzed and reviewed our manuscript and research.

Conflict of interest. The authors confirm that this article content has no conflict of interest.

\section{REFERENCES}

[1] Abbot, J. I. O., Mace, R. (1999): Managing protected woodlands: Fuelwood collection and law enforcement in Lake Malawi National Park. - Conservation Biology 13(2): 418-421. https://doi.org/10.1046/j.1523-1739.1999.013002418.x.

[2] Adams, W. M., Hutton, J. (2007): People, parks and poverty: political ecology and biodiversity conservation. - Conservation and Society 5(2): 147-183.

[3] Agurto Adrianzén, M. (2013): Improved cooking stoves and firewood consumption: Quasi-experimental evidence from the Northern Peruvian Andes. - Ecological Economics 89: 135-143. https://doi.org/10.1016/j.ecolecon.2013.02.010.

[4] Allendorf, T. D., Allendorf, K. (2012): The role of gender in park-people relationships in Nepal. - Human Ecology 40: 789-796. https://doi.org/10.1007/s10745-012-9510-7.

[5] Behera, B., Rahut, D. B., Jeetendra, A., Ali, A. (2015): Household collection and use of biomass energy sources in South Asia. - Energy 85: 468-480. https://doi.org/10.1016/j.energy.2015.03.059.

[6] Bell, R. H. V., McShane-Calzi, E. (1986): Monitoring of Illegal Activity and Law Enforcement in African Conservation Areas. - In: Bell, R. H. V., McShane-Calzi, E. (eds.) Conservation and Wildlife Management in Africa. US Peace Corps, Washington DC, pp. 319-351.

[7] Bhatt, B. P., Sachan, M. S. (2004): Firewood consumption pattern of 9 dierent tribal communities in northeast India. - Energy Policy 32: 1-6.

[8] Biran, A., Abbot, J., Mace, R. (2004): Families and firewood: A comparative analysis of the costs and benefits of children in firewood collection and use in two rural communities in sub-Saharan Africa. - Human Ecology 32(1): 1-25. https://doi.org/10.1023/B:HUEC.0000015210.89170.4e.

[9] Brown, G., Tolsma, A., Murphy, S., Miehs, A. (2009): Ecological Impacts of Firewood Collection-a Literature Review to Inform Firewood Management on Public Land in Victoria. - Victorian Government Dept. of Sustainability and Environment, Melbourne.

[10] Cardoso, M. B., Ladio, A. H., Lozada, M. (2013): Fuelwood consumption patterns and resilience in two rural communities of the northwest Patagonian steppe, Argentina. Journal of Arid Environments 98: 146-152. https://doi.org/10.1016/j.jaridenv.2012.09.013.

[11] Carey, B., Gill, J. D. (1980): Firewood and Wildlife. - Forest Service Research Note-299. U.S. Department of Agriculture, Forest Service, Northeastern Forest Experiment Station, Broomall, PA.

[12] Chettri, N., Sharma, E., Deb, D. C., Sundriyal, R. C. (2002): Impact of firewood extraction on tree structure, regeneration and woody biomass productivity in a trekking corridor of the Sikkim Himalaya. - Mountain Research and Development 22(2): 150-158. https://doi.org/10.1659/0276-4741(2002): 22[0150:IOFEOT]2.0.CO;2. 
[13] Démurger, S., Fournier, M. (2011): Poverty and firewood consumption: A case study of rural households in northern China. - China Economic Review 22(4): 512-523. https://doi.org/10.1016/j.chieco.2010.09.009.

[14] Ektvedt, T. M. (2011): Firewood consumption amongst poor inhabitants in a semiarid tropical forest: A case study from Piura, northern Peru. - Norwegian Journal of Geography 65(1): 28-41. https://doi.org/10.1080/00291951.2010.549951.

[15] FAO (2017): Forestry Production and Trade. - http://www.fao.org/faostat/en/\#data/FO.

[16] Felix, M. (2015): Future prospect and sustainability of wood fuel resources in Tanzania. Renewable and Sustainable Energy Reviews 51: 856-862. https://doi.org/10.1016/j.rser.2015.06.034.

[17] Fox, J. (1984): Firewood consumption in a Nepali village. - Environmental Management 8(3): 243-249. https://doi.org/10.1007/BF01866966.

[18] He, G., Chen, X., Beaer, S., Colunga, M., Mertig, A., An, L., ... Liu, J. (2009): Spatial and temporal patterns of fuelwood collection in Wolong Nature Reserve: Implications for panda conservation. - Landscape and Urban Planning 92(1): 1-9. https://doi.org/10.1016/j.landurbplan.2009.01.010.

[19] Hegde, R., Enters, T. (2000): Forest products and household economy: a case study from Mudumalai Wildlife Sanctuary, Southern India. - Environmental Conservation 27(3): S037689290000028X. https://doi.org/10.1017/S037689290000028X.

[20] Khoa, T. M, Bhattachary, S. C., Amur, G. Q. (1999): A study of biomass as a source of energy in Vietnam. - International Energy Journal 21: 69-75.

[21] Kien, N. D., Harwood, C. (2017): Timber demand and supply in Northwest Vietnam: The roles of natural forests and planted trees. - Small-Scale Forestry 16(1): 65-82. https://doi.org/10.1007/s11842-016-9343-0.

[22] Kim, L. T. T., Nichols, J. D., Brown, K. (2016): Firewood extraction and use in rural Vietnam: a household model for three communes in Ha Tinh Province. - Agroforestry Systems 91(4): 649-661. https://doi.org/10.1007/s10457-016-9993-0.

[23] Kimemia, D., Annegarn, H. (2011): An urban biomass energy economy in Johannesburg, South Africa. - Energy for Sustainable Development 15(4): 382-387. https://doi.org/10.1016/j.esd.2011.10.002.

[24] Kumar, R., Shahabuddin, G. (2005): Effects of biomass extraction on vegetation structure, diversity and composition of forests in Sariska Tiger Reserve, India. - Environmental Conservation 32(3): 248. https://doi.org/10.1017/S0376892905002316.

[25] Lan, L. Van, Ziegler, S., Grever, T. (2002): Utilization of forest products and environmental services in Bach Ma. - International Conservation 2011(October): 1-9.

[26] Lindroos, O. (2011): Residential use of firewood in Northern Sweden and its influence on forest biomass resources. - Biomass and Bioenergy 35(1): 385-390. https://doi.org/10.1016/j.biombioe.2010.08.054.

[27] Maes, W. H., Verbist, B. (2012): Increasing the sustainability of household cooking in developing countries: Policy implications. - Renewable and Sustainable Energy Reviews 16(6): 4204-4221. https://doi.org/10.1016/j.rser.2012.03.031.

[28] Maikhuri, R. K. (1991): Fuelwood consumption pattern of different tribal communities living in Arunachal Pradesh in North-East India. - Bioresource Technology 35(3): 291296. https://doi.org/10.1016/0960-8524(91)90127-6.

[29] Marquez-Reynoso, M. I., Ramírez-Marcial, N., Cortina-Villar, S., Ochoa-Gaona, S. (2017): Purpose, preferences and fuel value index of trees used for firewood in El Ocote Biosphere Reserve, Chiapas, Mexico. - Biomass and Bioenergy 100: 1-9. https://doi.org/10.1016/j.biombioe.2017.03.006.

[30] Mislimshoeva, B., Hable, R., Fezakov, M., Samimi, C., Koellner, T., Mislimshoeva, B., ... Abdulnazarov, A. (2014): Factors Influencing Households' Firewood Consumption in the Western Pamirs , Tajikistan. - Mountain Research and Development 34(2): 147-156.

[31] Mon, M. S., Mizoue, N., Htun, N. Z., Kajisa, T., Yoshida, S. (2012): Factors affecting deforestation and forest degradation in selectively logged production forest: A case study 
in Myanmar. - Forest Ecology and Management 267: 190-198. https://doi.org/10.1016/j.foreco.2011.11.036.

[32] Nansaior, A., Patanothai, A., Rambo, A. T., Simaraks, S. (2011): Climbing the energy ladder or diversifying energy sources? The continuing importance of household use of biomass energy in urbanizing communities in Northeast Thailand. - Biomass and Bioenergy 35(10): 4180-4188. https://doi.org/10.1016/j.biombioe.2011.06.046.

[33] Naughton-Treves, L., Kammen, D. M., Chapman, C. (2007): Burning biodiversity: Woody biomass use by commercial and subsistence groups in western Uganda's forests. Biological Conservation 134(2): 232-241. https://doi.org/10.1016/j.biocon.2006.08.020.

[34] Nyambane, A., Iiyama, M., Johnson, O., Mugo, P., Njenga, M. M, Oballa, P., Ochieng, C. (2014): Sustainable firewood access and utilization. - Technical Brief 2014(May): 4.

[35] Obua, J., Banana, A., Turyahabwe, N. (1998): Attitudes of local communities towards forest management practices in Uganda: the case of Budongo forest reserve. Commonwealth Forestry Review $77(2)$ : 113-118. https://doi.org/10.5923/j.ijaf.20150502.07.

[36] Ormsby, A., Kaplin, B. A. (2005): A framework for understanding community resident perceptions of Masoala National Park, Madagascar. - Environmental Conservation 32(2): 156. https://doi.org/10.1017/S0376892905002146.

[37] Pattanayak, S. K., Sills, E. O., Kramer, R. R. A. (2004): Seeing the forest for the fuel. Environment and Development Economics 9(2): 155-179. https://doi.org/10.1017/S1355770X03001220.

[38] Rantala, S., Tyynela, T., Vickers, M. (2004): Organic matter fuel briquettes as a forest conservation tool in Lake Malawi National Park. - Southern African Forestry Journal 202(1): 55-60. https://doi.org/10.1080/20702620.2004.10431790.

[39] Reyes, R., Nelson, H., Zerriffi, H. (2018): Firewood: Cause or consequence? Underlying drivers of firewood production in the South of Chile. - Energy for Sustainable Development 42: 97-108. https://doi.org/10.1016/j.esd.2017.10.006.

[40] Sassen, M., Sheil, D., Giller, K. E. (2015): Fuelwood collection and its impacts on a protected tropical mountain forest in Uganda. - Forest Ecology and Management 354: 56-67. https://doi.org/10.1016/j.foreco.2015.06.037.

[41] Schueftan, A., Sommerhoff, J., Gonzalez, A. D. (2016): Firewood demand and energy policy in south-central Chile. - Energy for Sustainable Development 33: 26-35. https://doi.org/10.1016/j.esd.2016.04.004.

[42] Sousa-Silva, R., Ponette, Q., Verheyen, K., Van Herzele, A., Muys, B. (2016): Adaptation of forest management to climate change as perceived by forest owners and managers in Belgium. - Forest Ecosystems 3(1): 22. https://doi.org/10.1186/s40663-016-0082-7.

[43] Tabuti, J. R. S., Dhillion, S. S., Lye, K. A. (2003): Firewood use in Bulamogi County, Uganda: Species selection, harvesting and consumption patterns. - Biomass and Bioenergy 25(6): 581-596. https://doi.org/10.1016/S0961-9534(03)00052-7.

[44] Thapa, S., Chapman, D. S. (2010): Impacts of resource extraction on forest structure and diversity in Bardia National Park, Nepal. - Forest Ecology and Management 259(3): 641649. https://doi.org/10.1016/j.foreco.2009.11.023.

[45] Tung, N. D. (2009): The present state: potential and future of electrical power generation from biomass residues in Vietnam. - Agricultural Engineering XI(1111): 1-12.

[46] Tweheyo, M., Hill, C. M., Obua, J. (2005): Patterns of crop raiding by primates around the Budongo Forest Reserve, Uganda. - Wildlife Biology 11(3): 237-247. https://doi.org/10.2981/0909-6396(2005)11[237:POCRBP]2.0.CO;2.

[47] Victor, N., Victor, D. (2002): Macro patterns in the use of traditional biomass fuels. https://pesd.fsi.stanford.edu/sites/default/files/macro_patterns.pdf.

[48] Wang, X., Felbermeier, B., Kateb, H. E., Mosandl, R. (2015): Household forests and their role in rural livelihood: a case study in Shangnan County, Northern China. - Small-Scale Forestry 14(3): 287-300. https://doi.org/10.1007/s11842-015-9288-8. 
[49] Wangchuk, S., Siebert, S., Belsky, J. (2014): Fuelwood use and availability in Bhutan: implications for national policy and local forest management. - Human Ecology 42(1): 127-135. https://doi.org/10.1007/s10745-013-9634-4.

[50] Win, Z. C., Mizoue, N., Ota, T., Kajisa, T., Yoshida, S., Oo, T. N., Ma, H. (2018): Differences in consumption rates and patterns between firewood and charcoal: A case study in a rural area of Yedashe Township, Myanmar. - Biomass and Bioenergy 109: 3946. https://doi.org/10.1016/j.biombioe.2017.12.011.

\section{APPENDIX}

\section{Household survey questionnaire}

\section{General information}

\begin{tabular}{|c|c|c|}
\hline Date: & \multicolumn{2}{|c|}{ Village: ............... } \\
\hline Name: .................; Age ........... & \multicolumn{2}{|c|}{ Ethnic: .............; Education: ............ } \\
\hline Gender: ..............; & \multicolumn{2}{|c|}{ Number of family: ...... / Children: ................... } \\
\hline Household size: ........... $\mathrm{m}^{2}$, & \multicolumn{2}{|c|}{ Estimated income: ....................VND/month } \\
\hline \multicolumn{3}{|l|}{ Living-years in buffer zone: ..... year } \\
\hline Cultivated working time & $\square$ Full-time & $\square$ Part-time \\
\hline \multirow[t]{2}{*}{ Land use of family } & $\square$ Agriculture & $\square$ Forest \\
\hline & $\square$ Plantation & $\square$ Other \\
\hline
\end{tabular}

\section{Firewood aspect}

1. What is your requirement from the forest?
a. [ ] Firewood
b. [ ] Timber
c. [ ] None-timber
d. [ ] Other, ....

Why?

2. Do your family use firewood?

Yes $\square$

No $\square$

3. How long has your family used firewood? ......... Years

What reason for?

- Where do you collect firewood?
a. [ ] $\mathrm{Pu} \mathrm{Hu}$
b. [ ] Household forest
c. [ ] Agriculture land
d. [ ] Buy
d. [ ] Other

For the purpose of...

a. [] Cooking b. [] Heating c. [] Boiling water d. [] Drying bamboo
e. [] Wine
f. [ ] Livestock
g. [ ] Other

4. What do you usually do when you collect firewood?

5. How do you transport firewood from field to house?
a. [] Head
b. [ ] Bicycle
c. [ ] Motorbike
d. [ ] Other, .....

6. How important is firewood as energy consuming in your family?

a. [ ] Unimportant b. [ ] Little important c. [ ] Medium d. [ ] Important e. [] Very

7. Why is firewood your main energy consumption?
a. [ ] Cheap
b. [ ] Nature
c. [ ] Efficiency
d. [ ] Other, .....

8. Do you sell firewood? $\quad$ Yes $\square ; \quad$ No $\square$

Why? 
9. Can you estimate firewood consume per day?

\begin{tabular}{|l|l|}
\hline Cooking and heating $(\ldots \ldots . \mathrm{person} / \mathrm{day})$ & $\ldots \ldots \ldots \ldots \ldots \ldots \ldots \mathrm{kg} / \mathrm{baskets}$ \\
\hline Heating & $\ldots \ldots \ldots \ldots \ldots \ldots \ldots \mathrm{kg} / \mathrm{baskets}$ \\
\hline Livestock & $\ldots \ldots \ldots \ldots \ldots \ldots \ldots \mathrm{kg} / \mathrm{baskets}$ \\
\hline Wine & $\ldots \ldots \ldots \ldots \ldots \ldots \ldots \mathrm{kg} / \mathrm{baskets}$ \\
\hline Bamboo drying & $\ldots \ldots \ldots \ldots \ldots \ldots \ldots \mathrm{kg} / \mathrm{baskets}$ \\
\hline Other & $\ldots \ldots \ldots \ldots \ldots \ldots . \mathrm{kg} / \mathrm{baskets}$ \\
\hline
\end{tabular}

10. There is a different quantity of firewood if compared to 10 years before?
a. [ ] Yes
b. [ ] No

Why?

11. Do you select plant species for firewood? $\quad$ Yes $\square$; $\quad$ No

12. What kind of species for firewood do you prefer?

13. Do you think about improving firewood?
a. [] Yes
b. [ ] No

If yes? What?

14. Do you think what government should support for energy consumption?

15. Do you see ranger's patrolling when collected firewood?
a. [ ] Rarely
b. [ ] Occasionally
c. [ ] Sometimes
d. [ ] Generally
e. [ ] Always
What happens?
a. [ ] Ignore
b. [ ] Talking
c. [ ] Arrest
d. [ ] Other, ......

16. Do you know forester communicated households?
a. [] Yes
b. [ ] No
c. [ ] Don't know

17. If yes, how good is the communication of forester and household?
a. [ ] Very bad
b. [ ] Bad
c. [ ] Normal
d. [ ] Good
e. [] Very good

18. Can you estimate the quality of firewood advice?
a. [] Very bad
b. [ ] Bad
c. [ ] Normal
d. [] Good
e. [ ] Very good

19. Do you think household agree on firewood advice?
a. [ ] Yes
b. [ ] Not much
c. [ ] No
d. [ ] Don't know

20. Do you receive firewood's advice from forester? $\quad \square$ Yes $\quad \square$ No

21. How do you know the communication between household and forester?

- Forester:
a. Usually go to and contact to commune
b. Support of technical and information on forest development
c. Propagandized policy
d. Others

- Family requirement:

a. Suggested forest protection and development

b. Require the excellent leader 


\section{Household Survey Questionnaire}

\section{Thông tin chung}

\begin{tabular}{|c|c|c|}
\hline Ngày: & \multicolumn{2}{|l|}{ Tên thôn: ................ } \\
\hline Họ và tên: ....................; Tuổi ............ & \multicolumn{2}{|c|}{ Dân tộc: ...............; trình độ học vấn: ............. } \\
\hline Giới tính: ..............; & \multicolumn{2}{|c|}{ Số khẩu: $\ldots \ldots \ldots \ldots \ldots \ldots \ldots \ldots$} \\
\hline Diện tích nhà: ............. m², & \multicolumn{2}{|c|}{ Ước tính thu nhập: ....................VND/Tháng } \\
\hline \multicolumn{3}{|l|}{ Số năm sống trong vùng đệm KBT: ..... năm } \\
\hline Thời gian làm nương & $\square$ Thời gian chính & $\square$ Bán thời gian \\
\hline \multirow[t]{2}{*}{ Các loại đất sử dụng gia đình có } & $\square$ Nông nghiệp & $\square$ Đất rừng \\
\hline & $\square$ Đất trồng cây công nghiệp & $\square$ Đất khác \\
\hline
\end{tabular}

\section{Quá trình củi}

1. Theo anh/chị nhu cầu nào trong gia đình đang cần hơn?
a. [ ] Củi
b. [ ] Gố
c. [ ] Lâm sản phụ
d. [ ] Khác, ....

Tại sao?

2. Gia đình anh/chị có dùng củi trong gia đình bạn không? $\quad$ Có $\square$ Không $\square$

3. Gia đình Anh/chị dùng củi đốt trong thời gian (hoặc không)? ........ năm

Nguyên nhân nào anh/chị quyết định như vậy?

- Anh chị lấy thu gom củi ở vùng nào?

a. [ ] Rừng Pu Hu b. [ ] Đất rừng nhà c. [] Đất nông ghiệp d. [] Mua d. [] Khác

- Mục đích sử dụng củi
a. [ ] Nấu ăn
b. [ ] Sưởi ấm
c. [ ] Nấu nước
d. [ ] Sấy măng

e. [ ] Nấu rượn

f. [ ] Chăn nuôi

4. Hoạt động nào anh/chị thường kết hợp với việc lấy củi?

5. Làm thế nào anh/chị vận chuyền củi về nhà? (chọn một lúc nhiều phương án)
a. [] Đi bộ/gùi
b. [ ] Xe đạp
c. [] xe máy
d. [ ] Khác, .....

6. Gia đình Anh/chị có quan trọng vấn đề nhiên liệu củi đốt trong thời gian qua?
a. [] Không quan trọng
b. [ ] Ít quan trọng
c. [] Bình
d. [ ] Quan thường
trọng
e. [ ] Rất quang trọng

7. Tại sao củi đốt lại là nguồn năng lượng cho gia đình?
a. [ ] Rẻ
b. [ ] Có sẵn
c. [ ] Có hiệu quả
d. [ ] Khác, .....

8. Anh/chị có bán củi nấu không? Có $\square$; Không

Tại sao?

9. Nếu anh/chị ước tính lượng củi dùng trong 1 ngày?

\begin{tabular}{|c|c|}
\hline Nấu ăn và nấu nước ( ........người/ngày) & ...........kg/bế \\
\hline Sưởi ấm & $\ldots \ldots \ldots \ldots \ldots \ldots \ldots \ldots . . \ldots \ldots k$ kg/bế \\
\hline$. \operatorname{lợ}+\ldots .$. bò $+\ldots \ldots \ldots)$ & $\mathrm{kg} / \mathrm{bế}$ \\
\hline Nấu rượn $(\ldots \ldots \ldots . .$. bó/kg; chai/lít ..........) & $\mathrm{kg} / \mathrm{bế}$ \\
\hline Sấy măng (..........măng/kg) & $. . \mathrm{kg} / \mathrm{b} \hat{\mathrm{e}}$ \\
\hline Khác: ................ & $\ldots \ldots \ldots \ldots \ldots \ldots \ldots \ldots . . \ldots \ldots k$ kg/bế \\
\hline
\end{tabular}




$$
-4249 \text { - }
$$

10. Nếu anh/chị so sánh gia đình có so với 10 năm về trước, có sự khác biệt về số lượng củi đun?
a. [ ] Có
b. [ ] Không

Tại sao?

11. Anh/chị có lựa chọn các loài cây làm củi đốt không? Có $\square$; $\quad$ Không $\square$

12. Loại cây nào anh/chị yêu thích dùng củi trong gia đình?

13. Anh/chị có nghĩ cần phải có cải thiện nguồn cung cấp củi?
a. [ ] Có
b. [] Không

Nếu có? Điều gì anh/chị nghĩ cần phải nâng cao nguồn cung cấp củi?

14. Hoạt động nhà nước nên hỗ trợ anh/chị thay đổi việc sử dụng năng lượng?

Liệt kê.

15. Anh/chị có nhìn thấy cán bộ kiểm lâm tuần tra rừng trong khi đi vào khu bảo tồn thu gom củi đốt?
a. [ ] Hiếm khi b. [ ] Thỉnh
c. [ ] Thường xuyên
d. [ ] Liên tục
e. [ ] Rất nhiều

Điều gì sẽ xảy ra?
a. [ ] Bỏ qua
b. [ ] Nói chuyện
c. [ ] Bị bắt lại
d. [ ] Khác, ......

16. Anh/chị có nghĩ đã có liên lạc giữa các hộ và cán bộ Lâm nghiệp trong thời gian qua?
a. [ ] Có
b. [] Không
c. [ ] Không biết

17. Nếu có, anh/chị cho biết mức độ liên lạc giữa các chủ hộ gia đình với KBT?
a. [] Rất xấu
b. [ ] Xấu
c. [ ] Bình thường
d. [] Tốt
e. [] Rất tốt

18. Anh/chị đánh giá chất lượng hỗ trợ trong hoạt động của cán bộ kiểm lâm về củi đốt?
a. [] Rất xấu
b. [ ] Xấu
c. [ ] Bình thường
d. [ ] Tốt
e. [ ] Rất tốt

19. Hộ gia đình có chấp nhận những tư vấn của cán bộ kiểm lâm về củi đốt?
a. [ ] Có
b. [ ] Không nhiều
c. [ ] Không
d. [] Không biết

20. Anh/chị có được hỗ trợ tư vấn trong sử dụng củi từ cán bộ KBT?
$\square$ Có
$\square$ Không

21. Theo anh/chị cho biết làm thế nào mức độ kết nối liên lạc hộ gia đình với KBT?

- Cán bộ lâm nghiệp:
a. Thường xuyên xuống và liên lạc với cộng đồng
b. Cung cấp hỗ trợ kỹ thuật và thông tin về phát triển rừng
c. Tuyên truyền chính sách

- Hộ gia đình:

a. Đề xuất các vấn đề liên quan đến lĩnh vực bảo vệ và phát triển

b. Cần có ban lãnh đạo/trưởng thôn uy tín

\section{ELECTRONIC APPENDIX}

\section{This article has an electronic appendix with basic data.}

